3. Пассов Е. И. Основы коммуникативной методики обучения иноязычному общению. Москва, 1989. 276 с.

4. Сайфуллин Р. Об эффективности использования информационнокоммуникационных технологий на уроках английского языка. URL: http://pedsovet.org/component/option,com_mtree/task,viewlink/link_id,16774 2/Itemid,118/ (дата звернення: 31.01.2021).

5. Шатилов С. Ф. О создании рациональной методики обучения иностранным языкам в средней школе. Иностранный язык в средней школе. 1990. № 2. С. 50-59.

6. Щукин А. Н. Современные интенсивные методы и технологии обучения иностранным языкам. Москва, 2008. 188 с.

\title{
DOI https://doi.org/10.30525/978-9934-26-041-4-91
}

\section{TECHNIKI I METODY OPTYMALIZACJI PROCESÓW ZAPAMIETTYWANIA I ODTWARZANIA INFORMACJI}

\author{
Zhdanov D. K. \\ Nauczyciel geografii \\ Liceum w Odesie $n r 82$ \\ m. Odesa, Ukraina
}

Reforma państwowego systemu edukacji powinna przede wszystkim zmienić niektóre kwestie metodologiczne. Nowe zadania edukacyjne nie mogą być rozwiązane w ramach modelu procesu edukacyjnego, w którym nacisk położono na zapamiętanie przekazanego materiału $\mathrm{i}$ formalne podejście do nauczania.

Artykuł poświęcony jest procesom zapamiętywania i odtwarzania informacji u dzieci w wieku szkolnym podczas zajęć sekcji «Co? Gdzie? Kiedy?» i opiera się na 20-letnim doświadczeniu zawodowym w szkolnych i pozaszkolnych placówkach oświatowych. Wśród nauczycieli, którzy zajmowali się tą kwestią, warto zwrócić uwagę na O.M. Matiushkina, jednego z klasyków naucznia sprawiającego problemy. I chociaż w artykułach Matiushkina problemy rozwoju pamięci u dzieci w wieku szkolnym są poruszane tylko pośrednio, przecież on oceniał skuteczność przyswajania przez uczniów nowego materiału, w tym i według procesów zapamiętywania i odtwarzania nowego materiału przez nich [5]. Istotny wkład w rozwój idei organizacji procesu edukacyjnego w szkołach w celu 
poprawy efektywności zapamiętywania nowego materiału należy do Nurali Latypovego, niestety mało znanego wśród nauczycieli badacza. Główne idee jego koncepcji edukacyjnej Latypov opublikował w pracy «Trening intelektualny» [4].

Wśród ukraińskich naukowców, którzy badali rozwój procesów pamięciowych u dzieci w wieku szkolnym, są I. P. Podlasii, I. D. Bekh, I. Y. Nikulina $i$ inni. Należy zwrócić uwagę, że badania nad rozwojem procesów pamięciowych u dzieci w wieku szkolnym dotyczą raczej kategorii wiekowej «młodszych uczniów», dlatego warto poświęcić więcej badań rozwojowi pamięci u uczniów klas 5-11.

Pamięć to złożona aktywność umysłowa. W jej strukturze można wyodrębnić oddzielne procesy. Jednym $\mathrm{z}$ głównych procesów jest zapamiętywanie. Zapamiętywanie jest połączeniem nowego $\mathrm{z}$ tym, co już jest w ludzkim umyśle [6].

Zapamiętywanie zaczyna się od fiksacji, która początkowo pojawia się mimowolnie $\mathrm{w}$ określonej czynności, i nie ma bezpośrednio na celu zapamiętania czegoś. Tak więc na początku zapamiętywanie odbywa się właśnie w ten sposób - nieumyślnie w procesie działania.

Jednym ze sposobów postrzegania i zapamiętywania dużych ilości informacji jest przejście na wyższe hierarchiczne poziomy informacji. Jeśli zastąpiać całe bloki informacyjne jedną koncepcją, można operować na całych zbiorach, których elementami są struktury niższego rzędu. Więc znajomość niektórych zasad może zastąpić zapamiętywanie ogromnej liczby faktów. Fakty te można odtworzyć w dowolnym momencie, korzystając z wyuczonych zasad. Nurali Latypov w swojej książce «Trening intelektualny» argumentuje, że znajomość niektórych zasad zastępuje zwykłe zapamiętanie wielu faktów. Szczególnie obrazowo można to zilustrować na przykładzie trygonometrii: zamiast zapamiętywać dziesiątki formuł, wystarczy znać zasady, które pozwalają ich wyprowadzać [4].

Jedno $\mathrm{z}$ opracowanych przez autora szkoleń przedstawia się następująco $[2,3]$ : studentom zaproponowano wybrać termin. Dalej należy zdefiniować wybrany termin. W tej definicji będą terminy, które również trzeba zdefiniować. Konieczne jest również zdefiniowanie tych terminów. Nowe definicje będą obejmować terminy, które również będą wymagały zdefiniowania. I tak to trwa 10-15 kroków. W rezultacie uczniowie otrzymują diagram pokazujący relacje między terminami i pojęciami z różnych dziedzin wiedzy. Takie szkolenie pozwala im lepiej zrozumieć interdyscyplinarne powiązania i dostrzec pozornie ukryte związki między różnymi dziedzinami wiedzy.

Główne parametry myślenia, z którymi pracują uczniowie sekcji «Co? Gdzie? Kiedy?», są następujące: 
- umiejętność załamania procesu rozumowania (poprzez wielokrotne rozwiązywanie tego samego typu pytań, uczniowie przestają być świadomi pewnych etapów procesu myślowego);

- elastyczność procesu myślowego, która wyraża się w łatwym i swobodnym przechodzeniu $\mathrm{z}$ jednej operacji umysłowej do drugiej, w różnorodności aspektów podejścia do odpowiadania na pytania, w uwolnieniu się od wpływu stereotypowych i szablonowych sposobów rozwiązywania zadań szkolnych;

- tendencja do ratowania procesu umysłowego, która wyraża się w poszukiwaniu najłatwiejszych sposobów «promowania» problemu;

- umiejętność generalizowania.

Rozważmy wyżej wymienioną informację na przykładzie dwóch pytań «Co? Gdzie? Kiedy?»:

1. W czasie wojny trzydziestoletniej miasto to nie wytrzymało naporu wroga i zostało zdobyte w walce. Aby przywrócić miastu dawną słąwę, kilka lat po pokoju westfalskim, burmistrz zorganizował tam słynną demonstrację. Proszę nazwać to miasto.

Odpowiedź: Magdeburg. Aby odpowiedzieć na to pytanie, należy skorzystać ze znajomości historii i fizyki. Dość często zagadnienia gier intelektualnych łączą kilka dyscyplin. Takie pytania budują «pomosty» między dyscyplinami akademickimi.

2. W XIX wieku hodowla drobiu w Republice Południowej Afryki była uważana za dochodową działalność: przy odrobinie szczęścia właściciel ptaka mógł zarabiać nie tylko na jajach, mięsie i piórach. Zapewne słynny pisarz wiedział o tym, chociaż $\mathrm{w}$ jego opowieści akcja toczy się nie $\mathrm{w}$ Republice Południowej Afryki, ale w Europie. Jeżeli zgadliście, jak ptak może wzbogacić żywiciela, proszę nazwać to opowiadanie.

Aby odpowiedzieć na to pytanie, należy wziąć pod uwagę następujący schemat: $Z$ czego słynie Republika Południowej Afryki? $\rightarrow$ Pierwszą rzeczą, która przychodzi na myśl, są diamenty. $\rightarrow$ Co ptaki mają wspólnego z diamentami? $\rightarrow$ Jest to dobrze znana pasja ptaków dla małych błyszczących przedmiotów. $\rightarrow$ Chodząc po wysypiskach skalnych w obszarach wydobycia diamentów w poszukiwaniu pożywienia, ptaki mogą połknąć diament. $\rightarrow$ Które opowiadanie opisuje takie informacje? $\rightarrow$

Odpowiedź: «Błękitny karbunkuł». Pytanie to łączy wiedzę z takich nauk jak: geografia, biologia (w tym ornitologia), literatura.

Jednak rozwiązanie różnych zadań nie zawsze następuje w wyniku jasnych i wyraźnych sekwencyjnych ruchów myślowych. W wielu przypadkach po nieudanych bezowocnych próbach rozwiązania problemu pojawia się nagłe przypuszczenie - pozornie przypadkowe i bezwarunkowe pojawienie się $\mathrm{w}$ umyśle idei rozwiązania, a sam człowiek nie jest $\mathrm{w}$ stanie określić tego faktu nagłości decyzji. 
Wiele przypadków nagłego i nieoczekiwanego na pierwszy rzut oka «oświecenia» thumaczy się tendencją do myślenia w zawalonych strukturach. Kiedy rozumowanie jest rozwinięte, łatwo jest prześledzić ścieżkę od jednej myśli do drugiej. Kiedy rozumowanie jest ograniczone, brakuje całego łańcucha pośrednich ogniw rozumowania, często trudno jest podążać tymi ścieżkami i wydaje się, że przejście od jednej myśli do drugiej nie jest logicznie motywowane.

Żadna informacja dostrzeżona przez mózg nie znika. Z biegiem czasu trudno jest uzyskać do niej dostęp. Informacje są jakby "zarchiwizowane», konwertowane do kompaktowego przechowywania [2,3]. U podstaw zjawiska nagłego przypuszczenia zwykle jest uogólnienie - nieświadome stosowanie ogólnych metod działania (lub odrębnej techniki), ogólnych zasad podejścia do decyzji, opartych na wspólnocie różnych schematów i zadań [2].

Aby to zilustrować, przedstawiamy następujące pytanie z quizu na temat «geologii»: «Czwarty okres ery paleozoicznej otrzymał swoją nazwę na cześć tego hrabstwa. Odpowiedź na pytanie pojawia się po słowach «czwarty okres». Wtedy można dłużej już nie słuchać pytania, natychmiast następuje kolejny łańcuch rozumowania: «czwarty okres może być tylko $\mathrm{w}$ erze paleozoicznej - czwarty okres paleozoiku - Dewon; ale najprawdopodobniej pytanie jest sformułowane inaczej: «Nazwa Devon pochodzi z hrabstwa Devonshire», to znaczy, odpowiedź powinna brzmieć «Hrabstwo Devonshire». Odpowiedź jest poprawna. Cały łańcuch rozumowania zajął kilka sekund.

Wprowadzenie tych zasad do systemu edukacji doprowadzi do znaczących zmian. Nie będzie najważniejszym «poznanie» faktów i formuł, o których szybko zapomina się, ale krytyczna i logiczna natura myślenia, w którym główną rolę będzie odgrywać rozumienie praw i logiczne wyprowadzenie niezbędnych informacji.

\section{Bibliografia:}

1. Бех І. Д. Особистість у контексті орієнтирів розвивального виховання // Інноватика у вихованні, вип. 1. - 2015.

2. Жданов Д. К. , Дидактичні можливості інтелектуальних ігор // Завуч, № 7, 2007.

3. Жданов Д. К., Можливості інтелектуальних ігор щодо розвитку мислення у дітей // Виховна робота в школі № 10, 2008.

4. Латыпов Н., Основы интеллектуального тренинга, СПБ - 2005.

5. Матюшкин А.М., Проблемные ситуации в мышлении и обучении, М.: «Педагогіка»-1972.

6. Никулина И.Я. Психология и педагогика, Одесса, СМИЛ - 2008. 